\title{
NEW AND RARE AUSTRALIAN TERMITES, WITH NOTES ON THEIR BIOLOGY.
}

\author{
By Gerald F. Hill, F.E.S. \\ (Plate xxxvi., and fifty-two Text-figures.)
}

During recent years and since the publication of Froggatt's monograph (1895-6) about 63 species have been added to the list of Australian Termites, bringing the total, inclusive of 5 species described in this paper, up to approximately 115 . Of this number no fewer than 49 have been described during the past two years.

In the following deseriptions Ridgway's Colour Standards and Nomenclature has been used as far as possible; measurements of wings are from the suture to the apex and across the widest part; all examinations were made in daylight and all figures drawn with the aid of a camera lucida; measurements are in millimeters.

The types of new species are in the writer's collection; the drawings for the Text-figures were made by the author.

$$
\begin{aligned}
& \text { Subfamily Stolotermitinae. } \\
& \text { Genus S t o lo T e R m es Hagen. } \\
& \text { Stolotermes victoriensis, n.sp. (Figs. 1-11.) } \\
& \text { I m a go. (Figs. 1-7). }
\end{aligned}
$$

Colour: Head, thorax, abdomen, antennae and palpi dark brown, proximal joints of antennae lighter than others; elypeus and labrum ochraceous tawny; legs buckthorn brown suffused with dark brown, mandibles ferrugineous. Wings very dark brown, blackish when folded.

Head (Fig. 1) large, rounded behind and on the sides, widest across the eves, flat on the summit, without median suture, clothed scantily with moderately large setae. Labrum large, rounded, not covering apical teeth of mandibles. Clypeus short and wide, anterior margin membranous. Eyes small and very prominent, a little higher than wide $(.235 \times .282)$, surrounded by pale-coloured membrane. Ocelli invisible except in cleared preparations, then very indistinct. A small deep depression on either side of the median line in line with the insertion of the antennae and immediately posterior to the postero-lateral angle of the elypeus. Mandibles (Fig. 2) with four angular teeth on the left and two angular and one broad tooth on the right. Antennae (Fig. 7) 16-jointed, 
3rd joint shortest of all, equal to, or noticeably longer than 4th, 5th-10th increasing in length and width, 10th-14th equal in length, 15th a little shorter, 16th shorter, elongate-oval. (In one example there is a rudimentary segment between the 3rd and 4th as described above).

Thorax: Pronotum very small, much narrower than head, nearly straight in front and on the sides, antero-lateral angles rounded, sides narrowed to the slightly sinuate posterior margin; behind the anterior margin a wide, pale, transverse mark, median suture distinct and passing posteriorly through the meso- and metanotum as a very dark line, clothed with scattered, long setae, most numerous at the sides. Meso- and metanotum with posterior margin nearly straight.

Wings (Plate xxxvi., Fig. 4) very dark brown, veins darker than membrane, the whole surface densely sculptured (Fig. 3) and elothed with dark, scattered setae, numerous along the costal margin excepting on the proximal one-third. Subcosta of forewing very short, joining the costa beyond the suture, wanting in the hindwing. Radius short, about one-fourth the length of the wing.
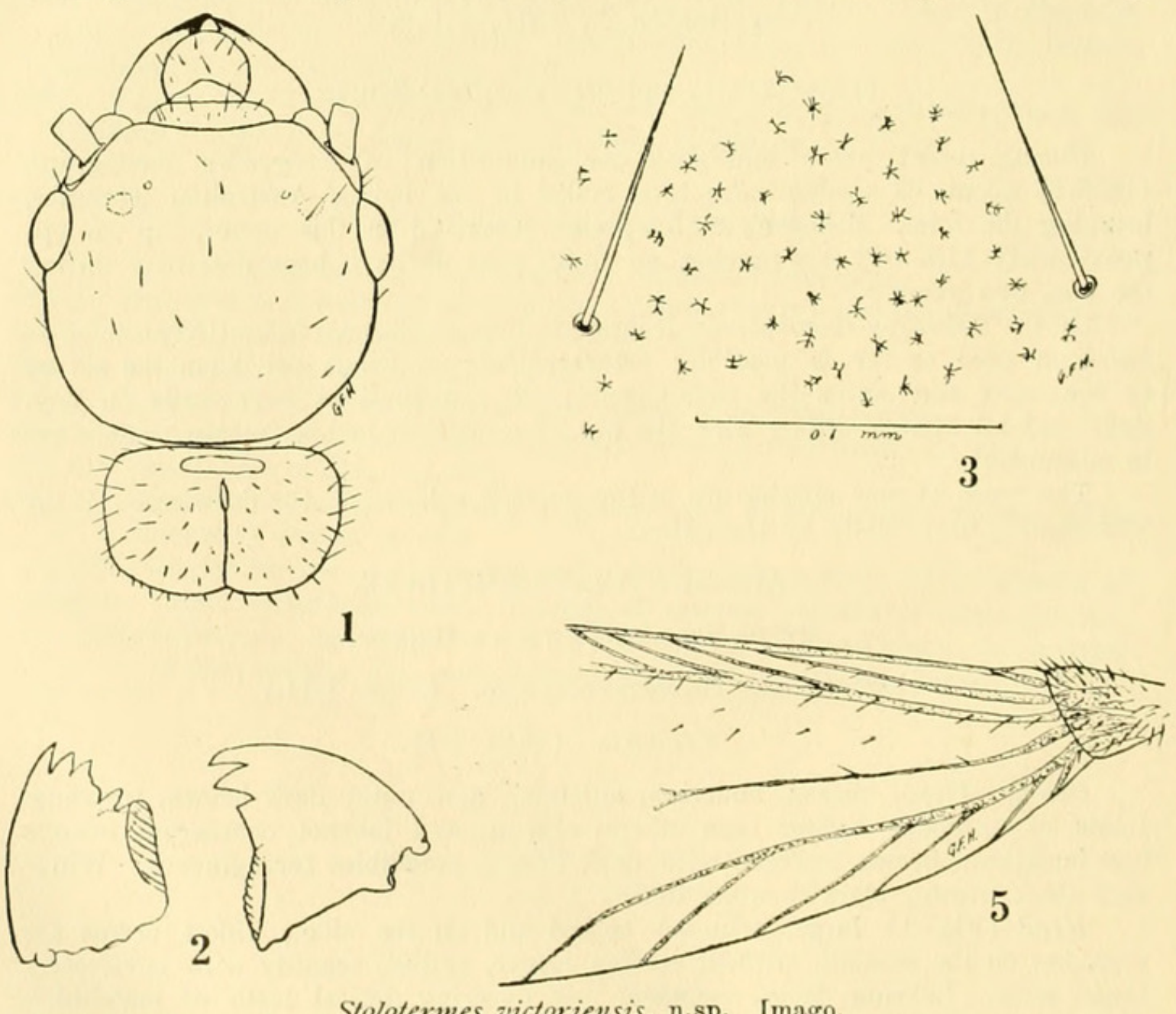

Stolotermes victoriensis, n.sp. Imago.

Fig. 1. Head and pronotum. Fig. 2. Mandibles. Fig. 3. Wing membrane.

Fig. 5. Stump and base of forewing.

Radial sector very short with 8 to 10 superior branches to the radius, that of the forewing branching from the media proximad of the suture, that of the hindwing distad of the suture. Media traversing the middle of the wing, dis- 
tinct only at the base, with about 6 inferior branches to the posterior margin of the wing. Cubitus with about 6 short, stout branches. Wing stumps (Fig. 5) with numerous long, pale setae, base of veins distinct, suture oblique, those of forewings larger than, but not reaching those of, hindwing.

Legs (Fig. 6) rather short and stout, with seattered, fine setae; empodium small; tibial spines $3: 3: 2$, not serrate.

Abdomen long and narrow, bluntly rounded at the apex. Cerei very prominent (.282 long), 3-jointed. Styli present in male.

Measurements :

Length with wings 11.0, without wings 6.5 .

Head: at and including eyes, wide 1.222 ; base to base of clypeus, long 0.990 ; base to apex of mandibles, long 1.363 .

Antennae (16-jointed) 2.350.

Mandibles: left, long .517, wide .329 ; right, long .470 , wide .470 .

Pronotum: long 0.50 ; wide 0.80 .

Wings (from suture) : forewing, long 9.00, wide 2.82; hindwing, long 8.50, wide 2.82 .

Abdomen, wide 1.50 .

Queen.

Lighter coloured than imago. Length 7.25 ; antennae mutilated, 7 joints.

$$
\text { Soldier. (Figs. 8-11.) }
$$

Colour: Cadmium yellow, a little darker in front; labrum like back of head; antennae paler; mandibles and spot at postero-lateral angle of elypeus
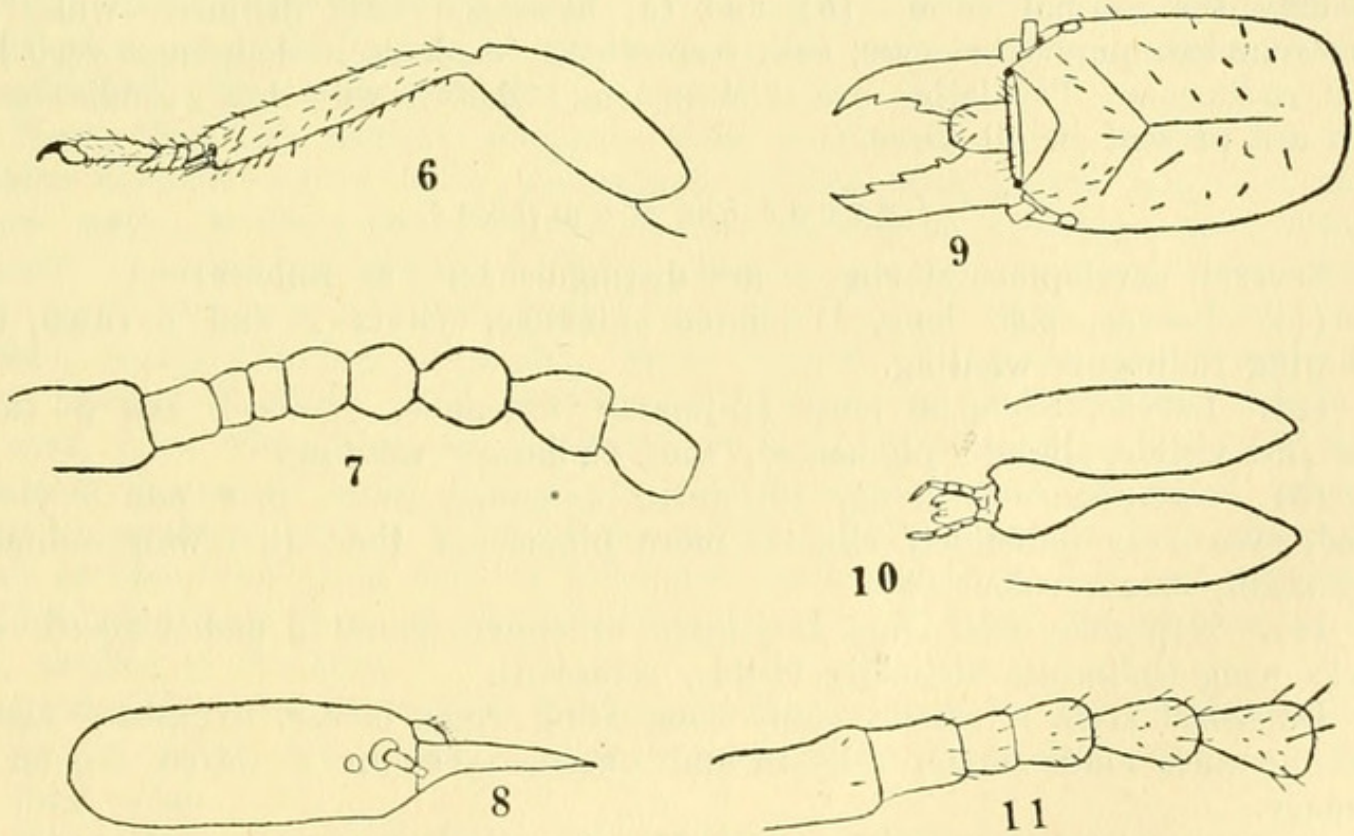

Stolotermes victoriensis, n.sp.

Figs. 6-7. Imago. 6. Hind leg; 7. Antennae, proximal segments,

Figs. 8-11. Soldier. 8. Head in profile; 9. Head from above; 10. Gula; 11. Antennae, proximal segments.

light castaneous, anteclypeus membranous; legs eream; abdomen lighter, with brown pattern along medial line of dorsum. 
Head (Figs. 8 and 9) long, rounded behind, slightly eurved on the sides, a little wider anteriorly than behind, very flat in profile, "Y" suture distinet, with a few reddish setae. Labrum large, longer than wide, truncate at the apex. Clypeus more or less triangular. Gula (Fig. 10) very long, narrow in the middle, one-tenth the width of head. Mandibles very long, with two broad and one narrow teeth on the left and two broad teeth on the right. Eyes small and indistinct, adjacent to antennal fossae. Antennae (Fig. 11) mutilated, more than 14-jointed, 3rd joint shortest, sometimes 3rd and 4th nearly equal, 5th10th increasing in length successively, slender.

Pronotum as in imago, but with seanty, moderately stout, reddish setae.

Legs short and moderately stout. Tibial spines $3: 3: 2$.

Abdomen elongate oval, bluntly pointed at the apex.

Measurements:

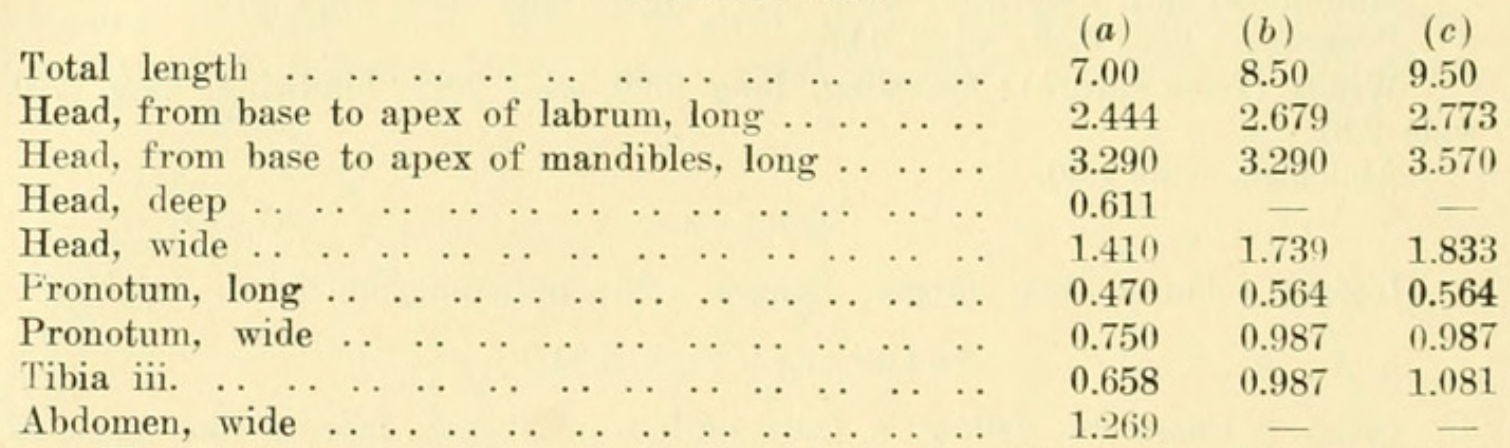

The above measurements are those of the only soldiers found in the type colony. The deseription and figures are from $(a)$, which appears to me most probably the normal form. $(b)$ and $(c)$ have the head distinctly wider and more rounded, pigmented eyes, and, respectively, moderately long and very long wing rudiments. The latter are thickened and clothed with long reddish setae. Styli are present in all three.

\section{Larvae and Nymphe.}

Several developmental stages are distinguishable, as follows:-

(1). Larvae, 3.05 long, 11-jointed antennae, joints 2 and 3 fused, eyes and wing rudiments wanting.

(2). Larvae, 5.00-5.50 long, 12-jointed antennae, joints 2 and 3 fused, eyes just visible, slightly pigmented, wing rudiments wanting.

(3). Nymphae, 6.00 long, 13-jointed antennae, joints 3, 4 and 5 closely fused, eyes very indistinct, slightly more pigmented than (2), wing-rudiments very small, eream eoloured.

(4). Nymphae, 6.50 long, 15-jointed antennae, joints 3 and 4 fused, eyes black, wing rudiments distinctly visible, setaceous.

Described from a small colony comprising eggs, larvae, nymphae, mature and immature alate forms, soldiers and queen, taken in a rotten $\log$ on 1 st January.

In his recent paper Mjöberg (1920) deseribed two new species in this genus, Stolotermes queenslandicus and St. australicus, from the tropical forest of Atherton District, North Queensland. Previously the genus contained only two species, St. brunneicornis Hagen, from Tasmania (alate forms only) and St. ruficeps Brauer, from New Zealand.

Affinities.-This species is evidently closely allied to St. brunneicornis, from which it differs in having no evident median suture in the head, no median false ocellus-like spot between the eyes, and distinctly different antennae. In length, 
with wings, Hagen's species exceeds that of the new species by $2 \mathrm{~mm}$.

Loc.-Victoria: Beaconsfield (F. E. Wilson).

\section{Subfamily CALOTERMITINAE.}

Genus P O R O T E R M E Hagen.

Porotermes adAMSONi (Froggatt).

These Proceedings, xxi., 1896, p. 532.

This species, originally described from specimens from New South Wales (Uralla), has not been recorded previously from Victoria.

I have received six nest series from Victorian collectors, one of which comprises an ovigerous queen which has been compared with an alate co-type. Associated with the queen were seven soldiers, eighteen large larvae, 3 young "second form" royalties and an adult de-alate male Calotermes obscurus Walker. The remaining colonies comprise soldiers, larvae and nymphae. In some colonies the soldiers vary considerably in size, but in each there are some which equal the co-types. The largest colony contains 10 soldiers and 190 larvae and nymphae.

Loc.-Victoria: Seaford (W. F. Hill), Ringwood (F. E. Wilson), Healesville (F. E. Wilson), Fern Tree Gully (F. P. Spry).

Calotermes (Glyptotermes) nigrolabrum, n. sp. (Figs. 12-19.)

$$
\text { King. (Figs. 12-14.) }
$$

Colour: Head and pronotum ehestnut, wing stumps darker, abdomen sandford brown, apex of abdomen, basal two-thirds of penultimate tergite and legs yellow ochre; labrum black; apex of clypeus white, membranous; antennae and mouth-parts sandford brown to chestnut; under surface yellow ochre, base of sternites buff yellow; tarsi brown.

Head (Fig. 12) slightly narrower than pronotum, widest across the eyes, rounded behind, surface finely shagreened, clothed with a few long and many minute setae. Labrum large, convex, slightly swollen on the sides, apex broadly truncate and fringed with fine setae. Clypeus more than three times wider than long, truncate in front, nearly straight behind. Eyes moderately large (0.282), nearly circular, projecting, finely faceted, lower margin 0.149 from lower margin of head. Ocelli broadly oval, oblique, in line with the middle of the eyes, from which they are separated by a distance equal to half their short diameter. Antennae (Fig. 13) ? 14-jointed, arising from a raised tubercle within a circular fossa in front of the middle of the eve, 1st joint short and broad at base, 2nd about half as long and much narrower, 3rd and 4th short, rounded, nearly as long as the following one, 6th, 7th and 8th narrow at the base, swollen at the apex.

Pronotum reniform, margin bent up, a deep depression behind the anterior margin on either side of the median line, margin with scanty fringe of short and long setae.

Wing stumps very dark in colour; those of forewings covering those of hindwings; the surface with seanty fine setae.

Legs (Fig. 14) moderately short and stout, elothed with fine, short setae. Tibial spines $3: 3: 3$, serrate.

Abdomen elongate, nearly cylindrical, with apices of segments fringed with scanty, moderately long setae. Cerei short and stout.

Measurements :

Total length, 6.25. 
Thorax and abdomen, long 5.00.

Head, from base to base of clypeus, long 1.128; from base to apex of labrum, long 1.316 ; at and including eyes, wide 1.222 .

Pronotum, long 0.658; wide 1.269.

Tibia iii. 0.930 .

Abdomen, wide 1.739 .

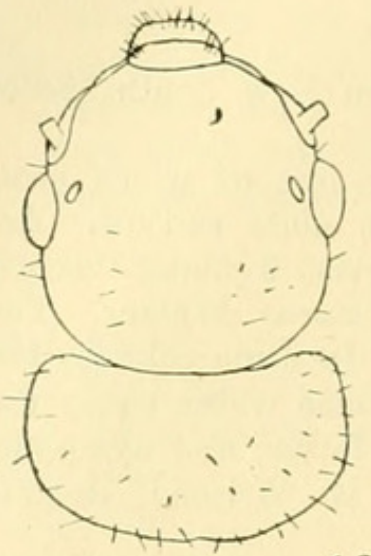

12
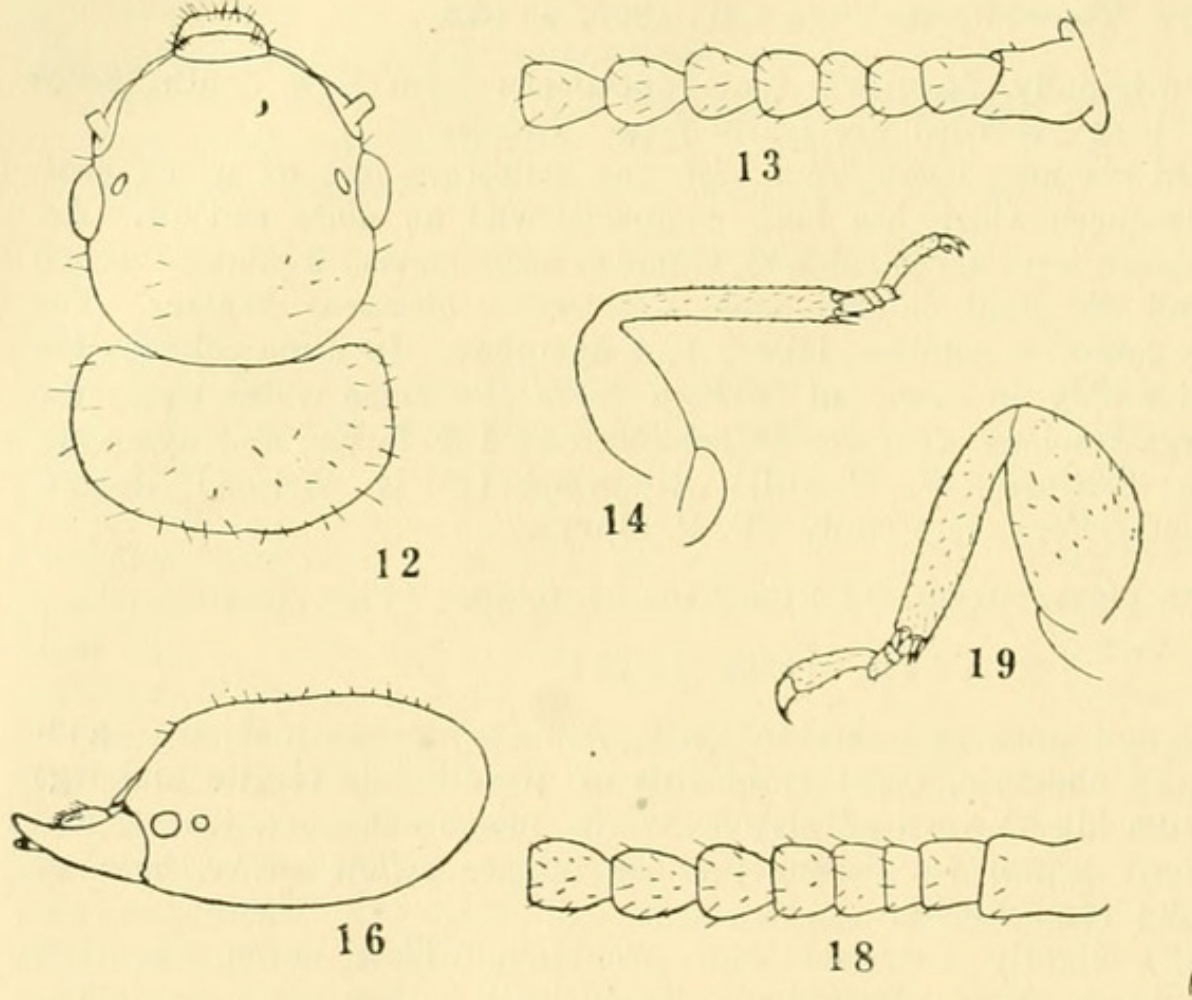

13
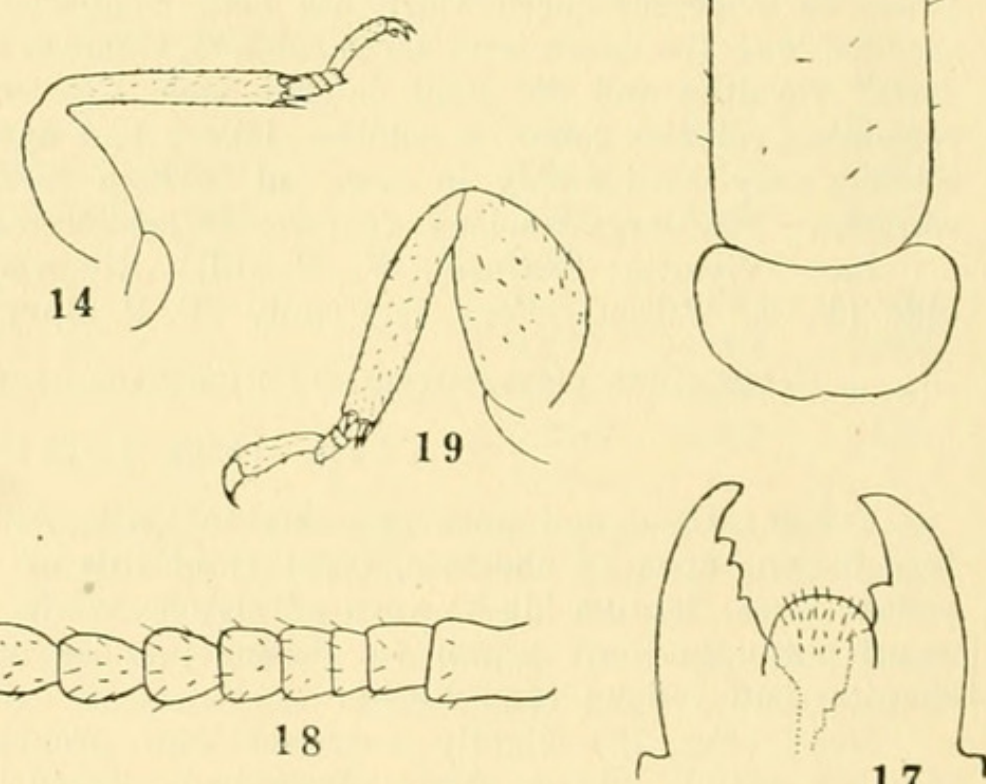

Calotermes (Glyptotermes) nigrolabrum, n.sp.

Figs. 12-14. Imago. 12. Head and pronotum; 13. Antennae, proximal segments; 14 . hind leg.

Figs. 15-19. Soldier. 15. Head and pronotum; 16. Head in profile;

17. Mandibles; 18. Antennae, proximal segments; 19. Hind leg.

\section{Queen.}

As above, excepting in size of abdomen, which is slightly longer and wider.

In all of the examples of kings and queens available for study the antennae are mutilated, only eight to ten joints remaining. Nymphs of the first form have 14-jointed antennae, which is probably the maximum number in the imago.

$$
\text { Soldier. (Figs. 15-19.) }
$$

Colour: Head yellow ochre, turning to cinnamon rufous anteriorly; margin of antennal fossa and base of mandibles dark eastaneous; mandibles black; antennae and pronotum einnamon rufous; meso- and metanotum and tergites of abdomen yellow ochre; legs and sternites of abdomen a little paler.

Head (Figs. 15 and 16) long and narrow, rounded behind, parallel on the sides, curving in gradually from the antennal fossae to the base of the mandibles; an obscure, pale "Y" suture on forehead, from the fork of which the front 
slopes to the base of the clypeus; clothed with a few moderately long, reddish setae. Eyes situated behind the base of the antennae, very small, pale coloured. Gula long and narrow, labrum short and broad $(0.230 \times 0.517)$ rounded in front. Clypeus broad and very narrow, anterior border slightly sinuate. Antennae (Fig. 18) 13-jointed, 1st joint short and wide, narrowest in the middle, 2nd about half as long, widest in the middle, 3rd short and wide, shortest of all, 4th and 5th short and wide, subequal, 6th narrow at base, widest beyond the middle. Mandibles (Fig. 17) $1.032 \mathrm{long}$, each with two teeth, those of the left mandible broad and blunt, those of the right more pointed.

Pronotum reniform, a little wider than head, clothed scantily with moderately large and small setae.

Legs (Fig. 19) short and stout, with scanty short, fine, setae. Tibial spines $3: 3: 3$.

Abdomen long and narrow, segments with a scanty fringe of moderately long and short setae. Cerci moderately long $(0.423)$. Styli present in males.

Measurements :

Total length (about) 9.00.

Head, from base to apex of clypeus, long 2.35; from base to apex of mandibles, long 3.15 ; wide 1.457 ; deep 1.316 .

Pronotum, long 0.752 ; wide 1.595 .

Meso- and metanotum, wide 1.692 .

Antennae (13-jointed) 1.786 .

Tibia iii. 0.940 .

Abdomen, wide 1.598 .

The soldiers vary somewhat in size, the above measurements being those of the majority. One example is only $5.25 \mathrm{long}$, with head and mandibles 2.440 in length, and 12-jointed antennae.

The nymphae (first form) in the type and other colonies are about 8.09 long and have 14-jointed antennae and unpigmented eyes. The wing rudiments are bright orange yellow.

Described from three colonies, taken in rotten logs on hill-side clad with tropical scrub (22nd June). The type colony comprised a king, queen, three soldiers and about 200 nymphae (first form) and larvae. Another comprised about 1000 larvae and nymphae, about 50 soldiers, three kings and three queens. Another comprised about 400 larvae and nymphae and 15 soldiers, but no imagos.

Affinities.-The imago appears to be most closely related to Calotermes (Glyptotermes) trilineatus Mjöb., from which it is distinguished, inter alia, by its lighter colour, dark wing stumps, smaller eyes and different head and pronotal measurements. From Calotermes (Glyp.) brevicornis Frogg. it is distinguished by its larger size (the former has a body length of $5.0 \mathrm{~mm}$., as against $6.25 \mathrm{~mm}$. in the new species), at least one more joint in the antennae and fewer tibial spines. The soldier castes of these two species differ considerably in size.

Loc.-North Queensland: Falm Island (G. F. Hill).

Calotermes (Glyptotermes) (?) obscurus Walker. (Figs. 20-29.)

I mago. (Figs. 20-25.)

Colour: Head and pronotum ochraceous orange, the latter suffused with brown; clypeus paler than head; legs and antennae tawny, suffused with brown; meso- and metanotum and wing-stumps very dark to blackish brown; dorsum of abdomen black, with the base of the first and the entire apical tergite brown; ventral surface brownish black, apex of abdomen, styli, and, in the male only, 
the middle of sternites one to four, paler; wings very dark, nearly as dark as sternites of abdomen, veins darker.

Head (Figs. 20 and 21) small, round, convex on the summit, with very few setae. Labrum small, slightly swollen on the sides, bluntly rounded in front. Anteclypeus large, three-tenths as long as wide, membranous. Eyes small $(0.188 \times 0.235)$, not prominent, finely faceted, lower margin distant 0.188 from lower margin of head. Ocelli small, oval, well separated from, and in

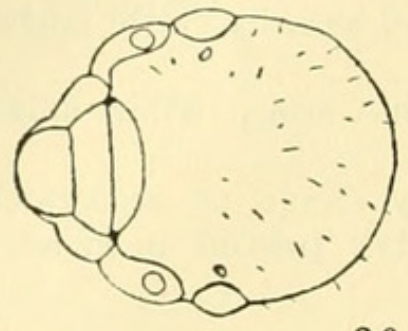

20

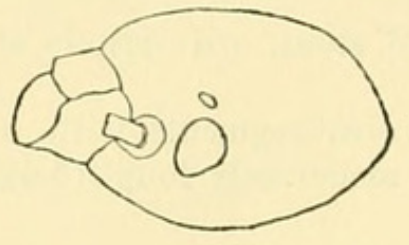

21

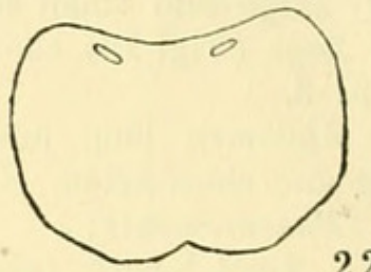

22

Calotermes (Glyptotermes)? obscurus Walker.

Figs. 20-22. Imago. 20. Head; 21. Head in profile; 22. Pronotum.

line with the middle of, the eyes. Antennae 13- (rarely 14-) jointed, the first joint short and stout, 2nd half as long and three fourths as wide as 1st, 3rd nearly as long as 2nd but wider at apex, 4th very little shorter than 3rd, shortest of all, rounded, 5th-12th increasing in length and width, 13th shorter or about as long as 12th, broadly oval.

Thorax: Pronotum (Fig. 22) large, wider than head, wider than long, anterior margin convex, sides rounded, postero-lateral angles nearly straight, posterior margin markedly sinuate, elothed sparsely with short, fine, pale setae, a deep depression behind the anterior margin on either side of the median line. Meso- and metanotum with dark median line on anterior two-thirds, posterior margin slightly sinuate.

Wings: Wing-stumps of forewings more than twice as long as those of hindwings, extencing posteriorly to the apex of the metanotum, with a few minute setae. Wings (Fig. 23, Pl. xxxvi.) nearly equal in length and width and bearing a few minute setae along the main veins; the membrane (Fig. 24, Pl. xxxvi.) is without setae, but, like the veins, it is covered with small sealelike spots, densest on the veins, but present in more or less irregular lines between them. In the forewing the subcosta is short, about one-fifth the length of the wing; the radius is about twice as long as the subcosta and bears a superior branch about the middle; the radial sector has about ten superior branches, the media is nearly parallel to the radial sector, joins the eostal margin at the apex of the wing, bears about 3 inferior branches towards its distal end and several short, indistinct, superior branches to the radial sector; the eubitus traverses the middle of the wing and bears about 12 simple or forked branches to the posterior margin. In the hindwing the subcosta is wanting; the radius bears three short, superior branches, the radial sector seven or eight; the media branches from the radial sector well beyond the suture, not at the base of the wing stump as in the forewing.

Legs (Fig. 25) short and moderately stout. Tibial spines 3: 3: 3, serrate. Abdomen nearly parallel on the sides, flattened dorso-ventrally, bluntly 
pointed in the male, more rounded in the female, segments with scanty, fine, short setae. Styli (male) long and slender. Cerei short and very stout.

\section{Measurements :}

Length, with wings 9.0-9.5; without wings 4.5 .

Head, from base to base of clypeus, long 1.081; from base to apex of labrum, long 1.410 ; at and including eyes, wide 1.128 ; deep 0.705 .

Antennae (13- or 14-jointed) long 1.786.

Pronotum, long 0.752 ; wide 1.222 .

Wings: forewings, long 7.0-7.25, wide 2.491; hindwings, long 6.75-7.0, wide 2.585 .

Tibia iii. 0.940 .

Abdomen, wide 1.222.

Soldier. (Figs. 26-29.)

Colour: Head ochraceous orange, darker anteriorly; labrum and antennae same colour as posterior part of head; legs and ventral surface yellow ochre.

Head (Figs. 26 and 27) long and narrow, less than half as wide as long (with jaws), nearly straight on the sides to the antennal fossae, rounded behind; front slightly rugose, sloping gently to the base of the clypeus, which is short, wide and nearly straight in front; dorsal surface in profile slightly convex, clothed with a few small setae; "Y" suture composed of fine but very distinct lines. Labrum very short and broad, bluntly rounded in front. Mandibles (Fig. 28) short and very stout, with three stout teeth on the left and two on
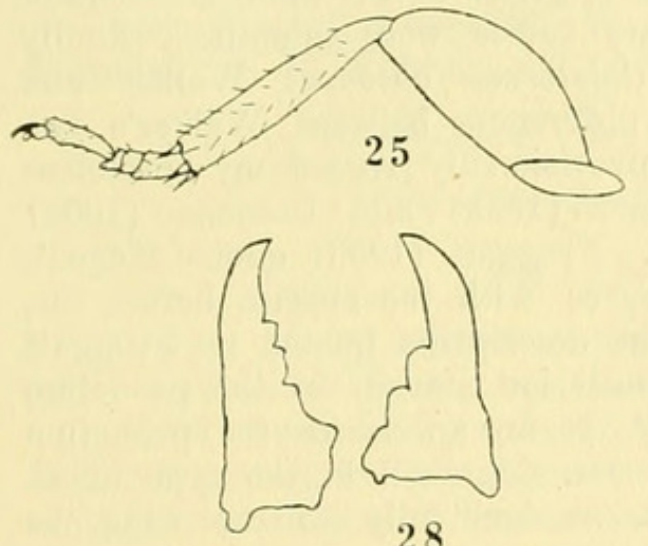

28

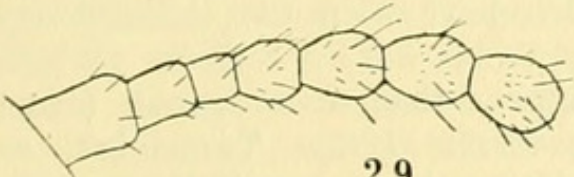

29

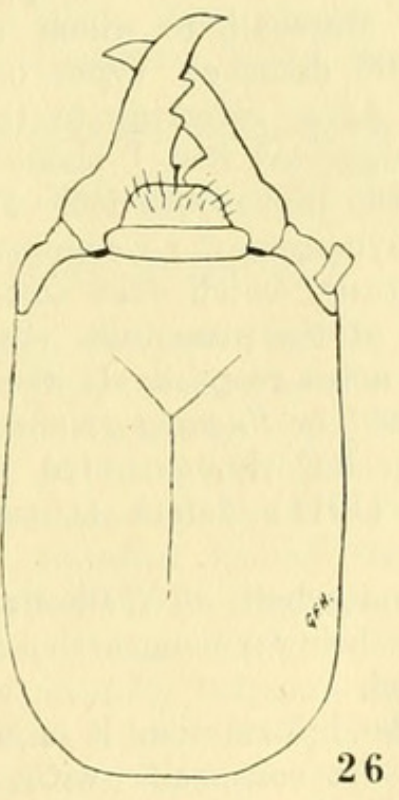

26

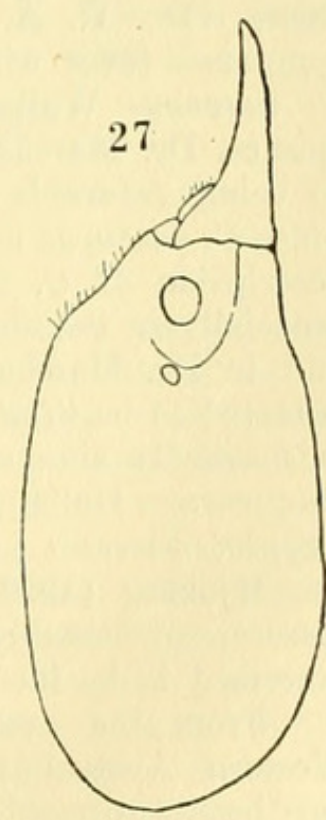

Calotermes (Glyptotermes)? obscurus Walker.

Fig. 25. Imago, hind leg.

Figs. 26-29. Soldier. 26. Head; 27. Head in profile; 28. Mandibles;

29. Antennae, proximal segments.

the right, all of the former and one of the latter projecting beyond the apex of the labrum. Eyes small, oval, whitish, adjacent to posterior margin of antennal fossae, the latter being a wide and shallow depression. Antennae (Fig. 
29) (12) 14-jointed, 1st joint short and stout, 2nd quadrate, about two-thirds the length of 1st, 3rd very short and narrow, smallest of all, 4th as long but wider than 2nd, rounded, 5th to 11th inereasing in length, 12th shorter and narrower than 11th. Gula long and narrow in the middle, where it is one-fifth the width of the head.

Thorax: Pronotum as in imago, very little narrower than head, margin narrowly bordered with ferrugineous. Meso- and metanotum with posterior margin slightly sinuate. In some individuals there is evident development of wing rudiments; in some these are hardly recognisable, in others they are as long as in nymphae of the first form.

Legs short and stout, with scanty setae, femora thickened. Tibial spines 3: $3: 3$, serrate.

Abdomen nearly parallel on the sides, bluntly-pointed at the apex, segments with seanty fringe of fine setae. Cerci short and stout. Styli long and slender.

\section{Measurements :}

Total length 6.50 .

Head, with jaws, long 2.820 ; base to apex of clypeus, long 2.162 ; wide 1.222 ; deep 1.081 .

Mandibles, long 0.950 .

Antennae (12-jointed) 1.222 .

Pronotum, long 0.752 ; wide 1.130 .

Abdomen, wide 1.081.

Identification.-I am in considerable doubt as to the identification of this species, and for this reason a full deseription is given of the alate and soldier eastes. Dr. G. A. K. Marshall, to whom alate forms were submitted, kindly compared them with the damaged types of Calotermes obscurus Walker an? C. convexus Walker. After referring to the differences between Walker's two species, Dr. Marshall suggested that I should provisionally regard my specimens as being referable to the first-mentioned. Hagen (1858) and Desneux (1904) place $C$. obscurus as a synonym of $C$. convexus. Froggatt (1906) quotes Hagen's description of $C$. convexus, which does not agree with the species before me, especially in the shape of the pronotum. In the description quoted by Froggatt and in Dr. Marshall's notes respectively the posterior margin of the pronotum is stated to be "flattened" or "nearly straight." In my specimens the pronotum is markedly sinuous posteriorly, as noted by Dr. Marshall in the type of $C$. obscurus. Holmgren (1911) refers C. convexus doubtfully to the subgenus Cryptotermes.

Mjöberg (1920) omits both of Walker's species from his list of Australian species, presumably as being amongst those which have been too incompletely described to be identified.

From the available information it would appear that $C$. obscurus (from Western Australia) is not conspecific with $C$. convexus (from Tasmania), as has been supposed. Whether the Victorian specimens here described are conspecific or not with the former can, in view of the damaged condition of the type, only be settled by the examination of a series of alate forms from the type locality (Swan River, W.A.), where Mr. J. Clark has, during the past two years, made a very thorough survey of the termite fauna. So far no alate forms have been discovered, but soldiers and nymphae recently collected by him may be conspecific, the only apparent difference being a slightly rugose front in the former caste. In view, however, of the slight difference in the soldiers of distinct species, this difference may well be specific. Froggatt further quotes 
Hagen as stating that $C$. convexus closely resembles $C$. improbus Hagen from Tasmania , but from the description of the latter, as quoted by Froggatt, it is evidently quite distinct from the species now deseribed by me as $C$. convexus Walker. Unfortunately very little is known of the termite fauna of Tasmania and until recently only three species have been recorded from that island. Of these Stolotermes brunneicornis Hagen is known only from three alate imagos, and Calotermes improbus Hagen only from a de-alate and damaged imago. A recently described species, Porotermes froggatti Holmgren, is unknown to me.

Biology: Of the nine colonies taken by Mr. W. Hill, eight were found in

the "Mallee"-like roots, trunks or branches of living or dead Eucalypts, and one in a verandah post, in association with a species of Leucotermes. In three eases a few soldiers and nymphae of Porotermos adamsoni (Froggatt) were found in the colony. C. obscurus has also been taken in colonies of Porotermes adamsoni in the same locality. Generally only a few soldiers and nymphae of the former were present, but in one instance a king only was found, apparently as consort of the gravid queen of the host species. Winged imagos were captured in January, June and July, at Seaford, and in Mareh, at Beaconsfield. The Lakes Entrance specimens were found in a Eucalyptus stump, in association with soldiers and workers of Eutermes fumigatus Brauer, or a very closely allied species. The Western Australian specimens, which I have provisionally referred to $C$. obscurus, were found in a rotten Banksia stump, with numerous soldiers, workers and larvae of Leucotermes clarki Hill.

In all cases the colonies were small, the largest comprising the soldiers and 300 larvae and nymphae. When alate forms were present they numbered less than thirty individuals.

Loc.-Vietoria: Seaford (W. F. Hill), Beaconsfield (F. E. Wilson), Lakes Entrance (F. E. Wilson) ; (?) S.W. Australia: Swan River (J. Clark).

\section{Calotermes (Glyptotermes) trilineatus Mjöb.}

Arkiv för Zoologi, Vol. 12, No. 15, 1920.

I m a go. (Figs. 30 and 31.)

Colour: Dorsal surface castaneous, abdomen lighter than head and thorax; under surface of thorax, legs, mouth-parts, antennae, first and middle of second and third sternites brussels brown, remainder of sternites darker but rather lighter than tergites; wings iridescent, anterior veins and eight proximal branches of eubitus dark brown, membrane between the latter suffused with brown.

Head narrower than prothorax, rounded behind and on the sides to the posterior margin of the eyes, the surface finely shagreened, clothed with numerous minute and a few larger setae. Labrum dark, with seattered pale setae, slightly swollen on the sides to the broadly truncate apex. Clypeus pale, anterior margin membranous, three times wider than long, sides rounded to the truncate apex, a group of three setae near each postero-lateral angle. Antennae (Fig. 30) 14-jointed, arising from a raised tubercle within a depression in front of the middle of the eye, 1st joint short and not greatly widened, curved on the sides, 2nd about half, as long and a little narrower, 3rd joint shortest and narrowest or as long but narrower than 4th, or rarely longer than 4th, 5th longer and wider than 4th, 6th-13th inereasing in length, 14th about as long but narrower than 13th, elongate-oval. Eyes very large and prominent, measuring vertically 0.329 , horizontally 0.376 , finely faceted, lower margin 0.188 from lower margin of head. Ocelli rather large, broadly oval, oblique, close to, and in line with, the middle of the eye. 
Thorax: Pronotum reniform, margin slightly bent up, more so anteriorly, a deep depression behind the anterior margin on either side of the middle line, posterior margin not emarginate, entire margin with a scanty fringe of long

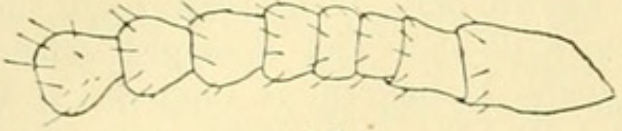

30
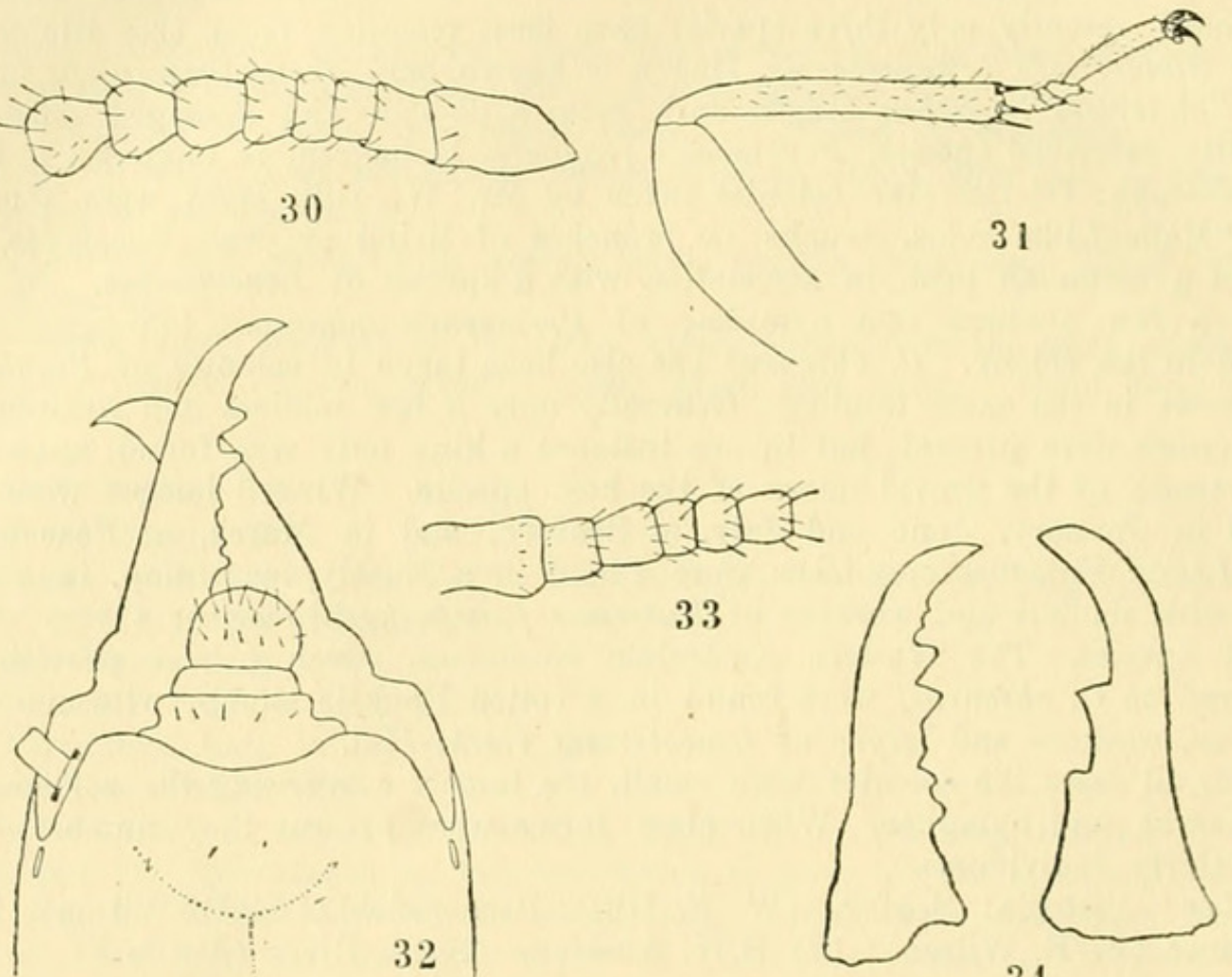

34

Figs. 30, 31. Calotermes (Glyptotermes) trilineatus Mjöb. Imago.

30. Antennae, proximal segments; 31 . Hind leg.

Figs. 32-34. (alotermes (Ncotermes) insularis White. Soldier.

32. Head; 33. Antennae, proximal segments; 34. Mandibles.

and short setae, fewer and shorter in front, and remainder of surface. Mesoand metanotum markedly sinuate posteriorly, similarly clothed.

Wings: Wing-stumps with a few pale setae, base of veins very distinct, cross-suture convex, anterior pair much larger than posterior, the former almost covering the latter. Wings slender, forewings a little longer and narrower than hindwings, costal margin with seanty fringe of setae, veins with scale-like appearance, membrane with minute scale-like spots, subcosta of the forewing very short, joining the costa just beyond the suture; radius about five times longer; radial sector unbranched, joining the costa before the apex; media very distinct, like the preceding, running elose to the radial sector and joining the costa at or very near the apex; cubitus traversing the middle of the wing, with about 13 inferior branches, the first four distinct, the next four very indistinet at their proximal end, the remainder indicated by rows of scale-like spots similar to those scattered over the membrane. In the hindwing the media branches from the radial sector well beyond the suture (about $1 \mathrm{~mm}$.)

Legs (Fig. 31) moderately short and stout, clothed with short fine setae, femora thickened. Tibial spines 3: $3: 3$, serrate.

Abdomen nearly eylindrical, bluntly rounded posteriorly, apices of the tergites fringed with short, pale setae. Cerci short $(0.450)$ and stout. 


\section{Measurements :}

Length with wings $11.0-11.50$; without wings 6.25 .

Thorax and abdomen, long 4.75.

Head, from base to posterior margin of clypeus, long 1.175; at and including eyes, wide 1.410 ; deep 0.800 .

Antennae 1.880.

Pronotum, long 0.800 ; wide 1.363 .

Wings: forewing, long 8.50, wide 2.068; hindwing, long 8.00-8.25, wide 2.256. Tibia iii. 1.270 .

Abdomen, wide 1.500 .

$$
K \text { ing and } Q \text { ueen. }
$$

Similar to the above, but slightly darker. Both have the antennae mutilated, ten or eleven joints only remaining. The abdomen of the latter is about $1 \mathrm{~mm}$. longer and a little wider than that of the alate form.

Biology: The king and queen described above were taken in a rotten log lying in dense tropical forest in the type locality. With them were found young larvae, nymphae of the first form, and soldiers, numbering in all several thousand individuals, of which soldiers comprised about 1 per cent. There were no eggs or very young larvae in the colony.

A portion of the log, eontaining soldiers and nymphae of the first form, was placed in a jar and kept moist from date of capture on 22nd May until 2nd August following, when the alate forms, here described, emerged.

Identification: By comparison of soldiers and nymphae with co-types of these eastes.

Loc.-N. Queensland: Malanda (G. F. Hill).

\section{Calotermes (Glyptotermes) afFinis Mjöb.}

Arkiv för Zoologi, Vol. 12, No. 15, 1920.

The above name appears to be preoceupied, having been used by Hagen for a fossil species from Prussian Amber (Hag. Linn. p. 53).

\section{Calotermes (Neotermes) insularis White.}

$$
\text { Soldier. (Figs. 32-34.) }
$$

Colour: Head orange rufous, mandibles black, labrum and antennae tawny, third joint of latter much darker, remainder of insect buff yellow.

Head (Fig. 32) very long, broadly rounded behind, curved on the sides, widest across the middle and sloping in to the base of the mandibles; front slightly rugose, sloping to the base of the clypeus. "Y" suture distinet. Labrum small, rounded. Clypeus moderately large; anteclypeus membranous, truneate in front. Antennae (Fig. 33) 17-jointed, 1st joint very large, twice as long as 2nd, narrowed in the middle, swollen at the apex, 2nd nearly quadrate, these two joints paler than others, 3rd as long and wide at the apex as 2nd, narrower at base, 4th smallest of all, 5th a little longer and wider than 4th, 6th-16th inereasing successively in length and decreasing in width at the base, 17th much shorter than 16th, oval. Gula long and narrow, about one-ninth as wide as head. Mandibles (Fig. 34).

Thorax: Pronotum very large, much wider than long, not quite as wide as head, anterior margin slightly concave and bent up, sides rounded, posterior margin slightly concave, margin all round darker than est of surface, darkest 
in front, with seanty reddish, stout setae. Meso- and metanotum with margin darkest, much narrower than pronotum.

Legs short and stout, elothed with seanty, red setae. Tibial spines 3: 3: 3 .

Abdomen narrow, elongate, flattened dorso-ventrally, traversed by a dark median line which passes anteriorly to the middle of the pronotum, tergites and sternites with seanty reddish setae. Cerci short and stout, apparently 2-jointed. Styli long and slender.

Measurements :

Total length 14.75 .

Thorax and abdomen, long 7.75.

Head and mandibles, long 7.00.

Head, base to anterior margin of clypeus, long 4.25 ; deep 2.58 ; wide 3.80 .

Antennae (17-jointed) 3.19 .

Pronotum, long 1.74 ; wide 3.48 .

Meso- and metanotum, wide 2.60 .

Tibia iii. 2.30 .

Abdomen, wide 2.96 .

Described from a small colony, eomprising two alate imagos, six soldiers, 40 nymphae, about twenty larvae and two neoteinie queens, taken in a hollow Eucalyptus stump, in January. This appears to be a rare species, known hitherto only in the alate form. It is recorded from New Zealand.

Loc.-Victoria: Seaford (W. F. Hill), Melton (F. P. Spry).

$$
\text { Calotermes (Cryptotermes) primus, n. sp. (Figs. 35-40.) }
$$

I mago. (Figs. 35-37.)

Colour: Ochraceous-tawny above, yellow ochre below; wings iridescent, anterior veins buckthorn brown.

Head small, longer than wide, rounded behind, the whole surface minutely shagreened and bearing seattered setae. Eyes very large $(0.329 \times 0.282)$ and prominent, coarsely faceted, lower margin half the vertical diameter from lower margin of head. Ocelli large, contiguous to inner margin of eye. Clypeus rather less than half as long as wide, anterior margin coneave, posterior margin convex. Labrum rather large, markedly convex and swollen on the sides, rounded in front. Left mandible with a large, sharp tooth at the apex, followed by a much smaller pointed one and a short, wide, eutting edge; right mandible with the two apical teeth as in left and a very much wider eutting edge towards the inner side. Antennae (Fig. 35) long, 16- (rarely 17-) jointed, springing from a circular eleft in front of the eye, 1st joint short, stout and slightly narrowed at the apex, 2nd three-fourths as long and nearly as wide at apex as 1st, 3rd, 4th and 5th equal, or 3rd shorter and narrower than 4th and 5th or, rarely, 3rd longer than 4th and 5th, as long as 2nd, 6th-15th increasing in length successively, 16th a little shorter and narrower than 15th, oval.

Pronotum much wider than long, concave in front, rounded on the sides to the rounded and slightly sinuate posterior, anterior margin and sides a little bent up and fringed with a few pale setae.

Wings (Fig. 36, Pl. xxxvi.) equal, rather less than four times as long as wide; a few minute setae on costal margin as far as junction of last branch of radial sector, and a few on radius and radial sector; under high power the principal veins have a scaly appearance. In the forewing the subcosta joins the costa just beyond the cross suture; the radius also is short and joins the costa a little before the middle of the wing; the radial sector has seven or eight 
superior branches, all of which join the costa before the apex of the wing, and sometimes a few indistinct inferior branches near the apex; the media branches within the wing stump, traverses the wing just above the middle and nearer to the cubitus than to the radial sector, has three or four branches, the second of which generally joins the radial sector towards the apex of the wing, where it is thickened; the eubitus is indistinet and has about 12 branches, some of which
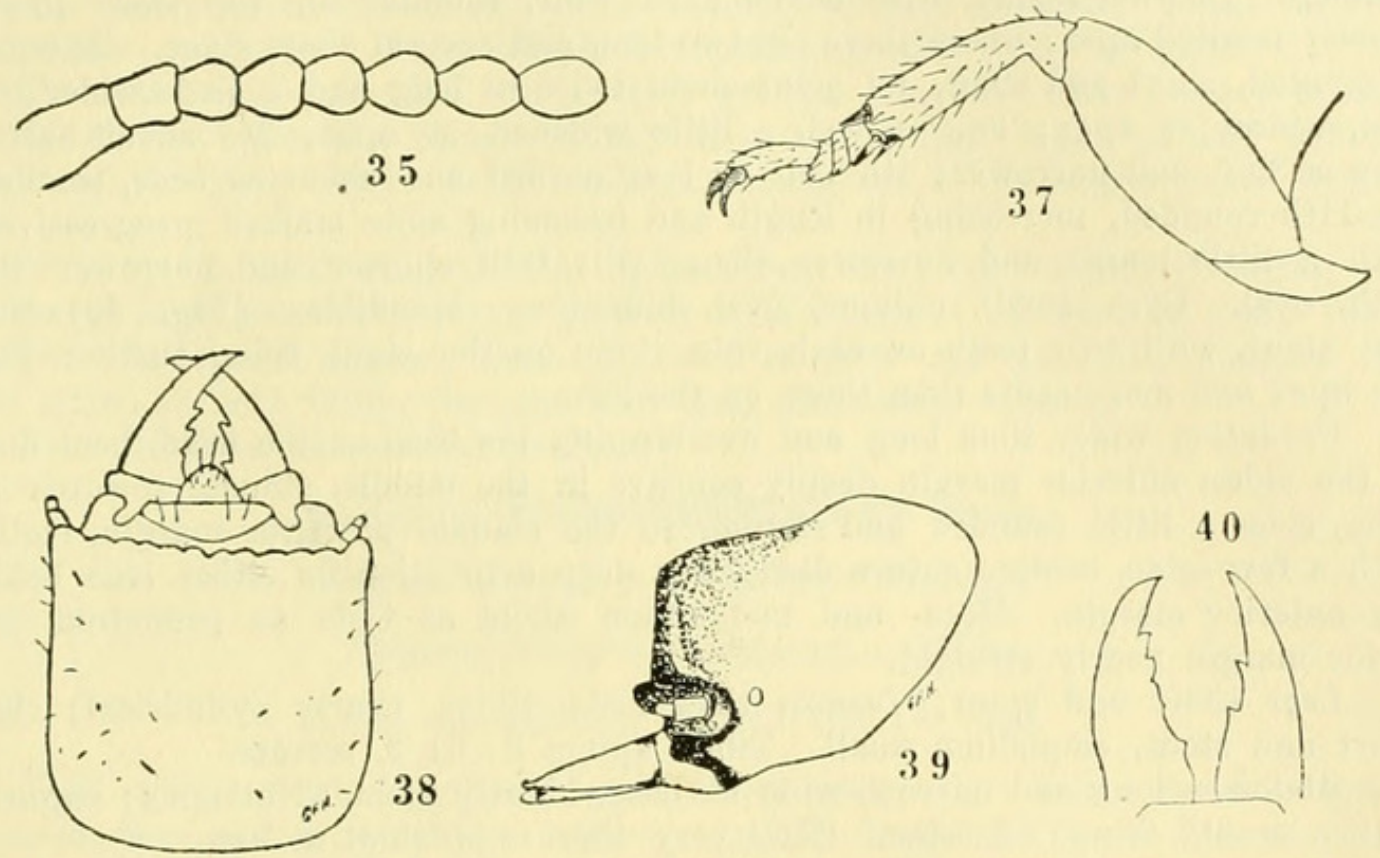

Calotermes (Cryptotermes) primus, n.sp.

Figs. 35, 37. Imago. 35. Antennae, proximal segments; 37 . Fore leg.

Figs. 38-40. Soldier. 38. Head; 39. Head in profile; 40. Mandibles.

terminate just below the apex of the wing. In the hindwing the subcosta is wanting and the media branches well beyond the eross suture. The wing-stumps of the forewing are very much larger than those of the hindwing, which they nearly cover, the surface bears a few minute setae and the eross suture is convex.

Legs (Fig. 37) short and moderately stout, tibiae slightly widened at apex and moderately setaceous; 1st tarsal as long as 2nd and 3rd together. Tibial spines 3: 3: 3, serrate.

Abdomen elongate, slightly widened beyond the middle, bluntly rounded at apex, segments with seanty fine setae. Cerei short and very stout at base.

\section{Measurements :}

Length with wings 9.50 ; without wings 4.50 . 0.987 .

Head, base to apex of labrum, long 1.128; at and including eyes, wide

Antennae 2.162.

Pronotum, long 0.517 ; wide 0.940 .

Wings, long 7.50 ; wide 2.25 .

Tibia iii. 0.940 .

Abdomen, wide 1.410 .

Soldier. (Figs. 38-40.) hazel.

Colour: Mandibles, elypeus and anterior half of head black, posterior half 
Head (Figs. 38 and 39) very short, wide and deep, sides widening slightly to a prominence above the insertion of the antennae, abruptly truncate anteriorly, the upper margin sinuate and overhanging the deeply excavated front, anterior of dorsal surface of head rugose, the whole surface finely shagreened, a large, black tubercle on either side projecting forward from the front mesad of the antennal fossa. Clypeus indistinet, moderately large, anterior margin membranous. Labrum about twice as long as wide, rounded on the sides to the bluntly pointed apex, where there are two long and several short setae. Antennae 13-jointed, short and stout, 1st joint about twice as long and a little wider than 2nd, widest at apex; 2nd curved, a little widened at apex, 3rd about half as long as 2nd and narrower; 4th half as long as 3rd and ahout as wide, smallest; 5th-11th rounded, increasing in length and becoming more stalked progressively; 12th a little longer and narrower than 11th; 13th shorter and narrower than 12th, oval. Eyes small, oblique, oval, indistinet. Mandibles (Fig. 40) short and stout, with two teeth on each side, those on the right being further from the apex and more acute than those on the left.

Pronotum wider than long and overlapping the base of the head, bent down at the sides, anterior margin deeply concave in the middle, sinuate towards the sides, sides a little rounded and sloping to the sinuate posterior margin, elothed with a few setae, median suture distinct, a deep depression on either side behind the anterior margin. Meso- and metanotum about as wide as pronotum, posterior margin nearly straight.

Legs short and stout; femora thickened; tibiae nearly eylindrical; claws short and stout, empodium small. Tibial spines 3: 3: 3, serrate.

Abdomen long and narrow, wide at base, bluntly rounded at apex; segments with a seanty fringe of setae. Cerei very short and stout at base.

Measurements :

Total length 4.50-5.00.

Head, to apex of mandibles, long 1.645; from base to anterior margin of truncate front, long 1.128; wide 1.175 ; deep 0.940 .

Thorax and abdomen, long 3.290.

Pronotum, long 0.893 ; wide 0.175 .

Tibia iii. 0.800 .

Abdomen, wide 1.175 .

Biology: On 12th May, 1919, a colony of these termites was found in one of several pieces of imported soft wood (portion of a dismantled chicken coop) lying upon the ground. The wood was free from all traces of decay and was quite sound excepting for the damage done by the insects. The forms found in the passages comprised about 1 dozen soldiers, 80 alate adults and as many nymphae. Twenty days later another piece of wood from the same source and position was examined and found to contain numerous eggs, a mature king and queen, about 30 soldiers and many nymphs, but no alate forms. The queen was in a gallery not differentiated from those oceupied by the other forms and the eggs were scattered throughout all parts of the infested wood. A few soldiers and nymphae were taken on subsequent dates but no more alate forms were found in the remaining pieces of wood, although several were captured between 7.30 and 8.30 p.m. at a lamp in the house close by, i.e., one each on 2nd and 3rd June, 2 each on 8 th and 20th June. No further observations were made in this vicinity, but at my present residence, about $\frac{3}{4}$ mile distant, I took one winged form at a lamp on each of the following nights, i.e., 20th Aug. 1919, 6/8/20, $18 / 9 / 20,18 / 10 / 20,12 / 3 / 21,13 / 3 / 21,27 / 3 / 21,28 / 3 / 21,29 / 3 / 21,17 / 7 / 21$, $27 / 7 / 21$. 
On 2nd July, 1920, a young king and queen, with one egg, were found in a weevil hole (Euthyrrhinus meditabundus) in a dead mango branch. The egg lay on the floor of the hole about one inch from the entrance, which was tightly plugged with comminuted wood. On two subsequent occasions, two pairs (4th July) and one pair (12th Nov.) were found in similar positions in the same tree, but in these cases no egg was present, indicating that the termites had only recently entered the holes from which the weevils had emerged. From May to August the weather in Townsville is dry and generally ehilly at night.

From the facts recorded above it is evident that the alate imagos of this species do not leave the parent colony in a "colonising" flight at any definite season of the year but in small numbers throughout a prolonged period of the year.

It is to be noted, also, that no alate forms have been captured during the months of high temperature and greatest rainfall, as is the ease in many other species. It would appear, also, that new colonies are generally founded by alate pairs, as is, I think, the ease with most Australian species.

Loc.-N. Queensland: Townsville.

\section{Subfamily RHINOTERMITINAE Frogg.}

Genus P A R R H I N O T E R M E S Holmgr.

Farrhinotermes australicus Mjöb.

Arkiv för Zoologi, Vol. 12, No. 15, 1920.

This species was described by Mjöberg under the name Parrhinotermes queenslandicus and is referred to again on p. 126 under that name, but on pages 109 and 124 it is referred to as above, which would appear to be eorrect, since co-type specimens kindly presented to me by Professor Sjostedt are so labelled.

I have taken this species in the type locality (Malanda, N.Q., May, 1921) in a rotten $\log$ and in the vegetable debris beneath it. The colony comprised workers, soldiers, larvae and nymphae showing first appearance of wing buds, presumably from a nest situated in the soil in the vicinity. In their habits they appear to resemble very closely an undescribed species of Rhinotermes, which was taken in the same $\log$ and in others in the vicinity.

Genus RH i о T E R M S Hagen.

Rhinotermes (Schedorhinotermes) breinli, n. sp. (Figs. 41-50.)

I m a go. (Figs. 41-44.)

Colour: Ochraceous tawny above, yellow ochre below, wings hyaline, with eostal margin yellow ochre.

Head (Fig. 41) small, rounded behind and on the sides, flattened dorsoventrally, middle of dorsal surface depressed and faintly rugose about the fontanelle, seantily pilose. Labrum slightly convex, narrow at the base, widening on the sides to the width of the clypeus, with few reddish setae. Anteclypeus membranous, two-thirds as long as postelypeus, lobed in the middle. Postclypeus convex, divided medially by a ferrugineous suture, a little wider than long, slightly areuate behind, truncate in front, with a few reddish setae. Eyes very large and prominent, nearly cireular $(.399 \times .446)$. Ocelli large, broadly oval, separated from the eyes by a distance equal to one-third their long diameter. Fontanelle large, circular. Mandibles (Fig. 43) with four pointed teeth on left, two on the right, the latter separated by a small angular tooth. Antennae (Fig. 
42) 20-jointed, 1st joint short quadrate, nearly as wide as long, 2nd quadrate, half as long as first, as wide as long, 3rd a little longer and wider than 2nd, turbinate, 4th and 5th subequal, shorter and narrower than 3rd, slightly turbinate, 6th and 7 th subequal, similar to, but larger than 4th and 5th, 7th-20th moniliform.

Pronotum narrower than head, truneate and slightly bent up in front, sides rounded, posterior margin bilobed, outer margin fringed with moderately long reddish setae.
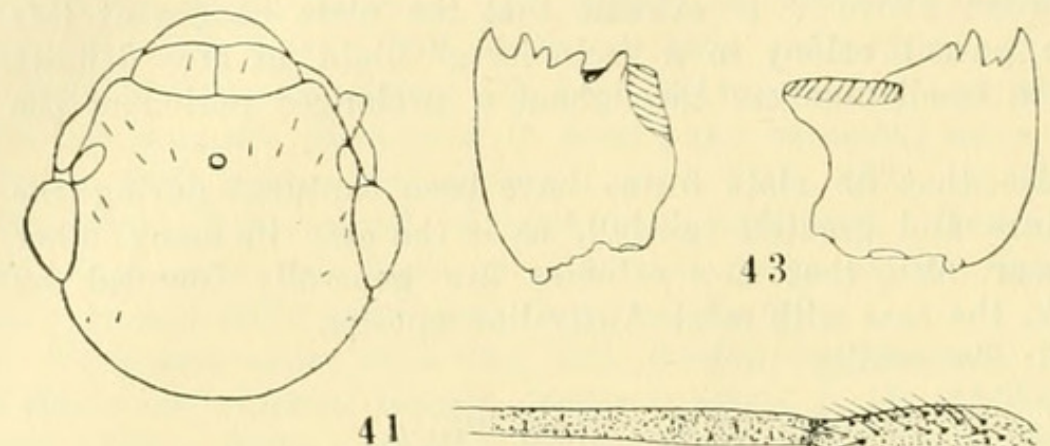

41

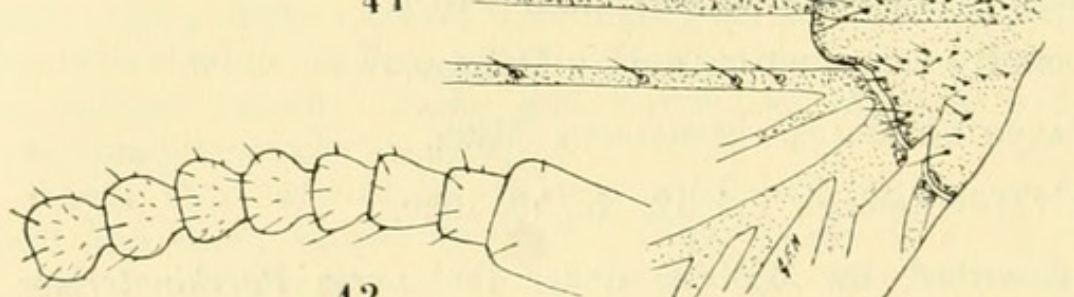

42

44

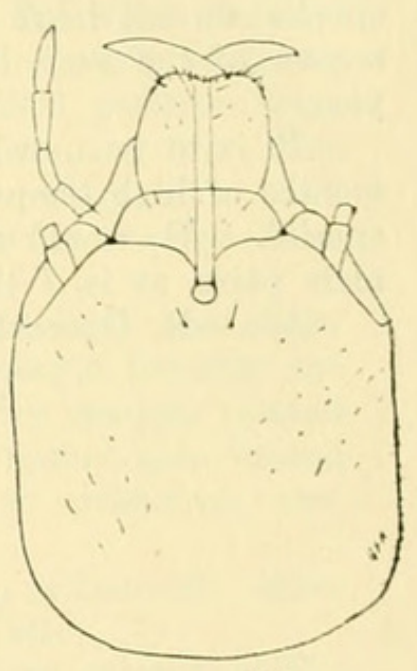

45

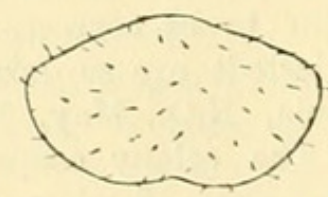

46

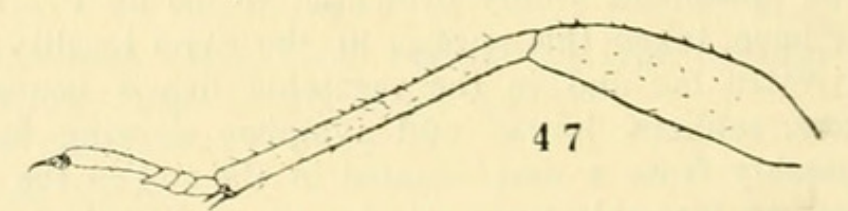

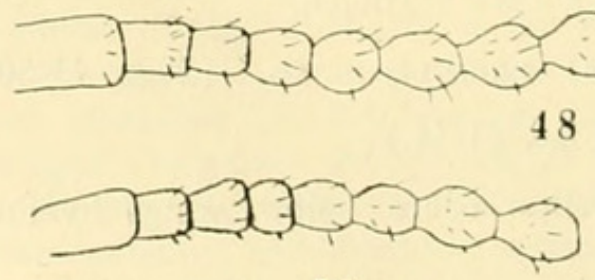

50

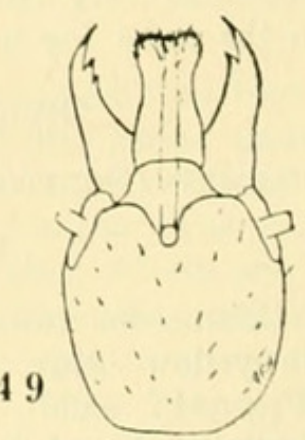

Rhinotermes (Schedorhinotermes) breinli, n.sp.

Fioss. 41.44. Imago. 41. Head; 42. Antennae, proximal segments;

43. Mandibles; 44. Base of hindwing.

Fig. 45-50. Soldier. 45. Head of large form; 46. Pronotum of large form;

47. Hind leg of large form; 48. Antennae of large form, proximal segments;

49. Head of small form; 50. Antennae of small form, proximal segments.

Wings: Wing-stumps (Fig. 44) large, moderately setaceous, anterior pair (1.03 long) twice as long as posterior pair. The first and second veins of foreand hindwings well separated to their junctions near apex of wing, the remain- 
ing veins very indistinct and irregularly branched; 2nd vein with a few setae along its entire length, remaining veins and membrane without setae or sculpture.

Legs moderately short and slender, femora a little thickened, with scattered reddish setae. Tibial spines $3: 3: 2$, long and slender.

Abdomen short, broad, rounded at the apex, apical half of tergites and sternites with very scanty setae, pleurites densely setaceous. Cerci short and stout. Styli present in male only.

Measurements :

Length with wings 11.0-11.5; without wings 7.0.

Head, from base to base of elypeus, long 1.03; at and including eyes, wide 1.41 ; deep 0.80 .

Antennae (20-jointed) 2.50 .

Pronotum, long 0.75 ; wide 1.18 .

Wings: forewings, long 9.00 , wide 2.85 ; hindwings, long 8.75 , wide 3.00 .

Tibia iii. 1.05 .

Abdomen, wide 1.64 .

\section{Soldier (Large form). (Figs. 45-48.)}

Colour: Yellow ochre above, antennae, legs and under surface slightly paler, clypeus hazel, mandibles ferrugineous.

Head (Fig. 45) large, quadrate, broadly rounded behind, sides widening a little to the posterior margin of the antennal fossae, then drawing in to the base of the mandibles, with scanty, stout, reddish setae. Labrum large, about twice as long as clypeus, covering apical teeth of mandibles, slightly swollen on the sides, deeply emarginate in front. Clypeus large, divided medially by a deep furrow which passes forward from the fontanelle to the apex of the labrum. Fontanelle large. Mandibles very stout with two apical teeth on the left, one on the right. Antennae (Fig. 48) 17- or 18-jointed, 3rd joint shortest but very little shorter than 4 th and 5th, 5th to 17 th moniliform, 18th small, broadly oval.

Pronotum (Fig. 46) wider than head, flat, with margin bent up, eonvex in front, sides sloping to the coneave posterior margin, clothed with seanty short, stout, red setae. Meso- and metanotum wider than pronotum and similarly clothed.

Legs (Fig. 47) rather slender. Tibial spines 3: 2: 2 .

Abdomen broad and flattened, widest in the middle, broad at base, bluntly rounded at the apex, segments with scanty setae. Cerci large, broad at base, conical at apex. Styli present.

Measurements :

Total length 5.5 .

Thorax and abdomen, long 3.10 .

Head, base to apex of labrum, long 2.20 ; wide 1.55 ; deep 0.89 .

Antennae (17- or 18-jointed) 1.92 .

Mandibles, long 1.03 .

Pronotum, long 0.66 ; wide 1.18 .

Tibia iii. 1.27.

Abdomen, wide 1.31.

$$
\text { Soldier (Small form). (Figs. } 49 \text { and 50.) }
$$
ous.

Colour: Yellow ochre, clypeus ochraceous tawny, mandibles light ferrugine-

Head (Fig. 49) small, widest behind the antennal fossae, narrower posteriorly, broadly rounded behind, elothed as in large form. Labrum long and 
slender, scantily setaceous at apex. Clypeus broad, nearly truncate in front. Antennae (Fig. 50) 16-jointed, 4th joint shortest, 5th-13th moniliform, 14th and 15th turbinate, 16th small, broadly oval. Mandibles large with dentition as in large form.

Pronotum of the same form as large form.

Legs as above, but tibia more thickened.

Abdomen: Styli present.

Measurements :

Total length 3.00 .

Thorax and abdomen, long 2.58.

Head, base to apex of labrum, long 1.55 ; wide 0.820 ; deep 0.517 .

Antennae (16-jointed) 1.70 .

Mandibles, long 0.658 .

Tibia iii. 0.893 .

Abdomen, wide 0.893 .

\section{Worker.}

Colour: Cream, with ferrugineous spot at postero-lateral angle of clypeus.

Head large, rounded behind and on the sides, flattened above, clothed with seattered setae. Labrum large, convex, swollen on the sides, rounded in front. Clypeus large, truncate in front, convex behind, divided medially by a distinct suture. Antennae 17- or 18-jointed, 3rd joint much longer than 2nd, 4th shortest of all. Mandibles with dentition as in imago.

Measurements :

Total length 5.50 .

Head, base to apex of labrum, long 1.410 .

Antennae 1.880.

Affinities: Two species, $R$. reticulatus Froggatt and $R$. intermedius Brauer, from Australia have been deseribed previously. The imago of the new species may be distinguished from the former by its darker colour, narrower head, much larger and more projecting eyes, much larger ocelli, narrow pronotum and greater space between ocelli and eyes.

R. breinli, n.sp. R. reticulatus Frogg.*

$\begin{array}{llllllllll}\text { Length with wings } & \ldots & \ldots & \ldots & \ldots & \ldots & \ldots & 11.0 & 11.0\end{array}$

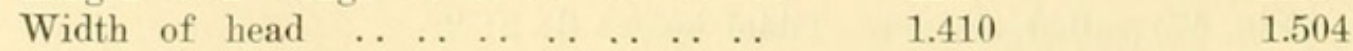

Width of pronotum $\ldots \begin{array}{llllllll}\text { W } & \ldots & \ldots & \ldots & \ldots & 1.175 & 1.265\end{array}$

$\begin{array}{llllllllllllll}\text { Diameter of eyes } \ldots & \ldots & \ldots & \ldots & \ldots & \ldots & \ldots & 0.376 \times 0.423 & 0.282 \times 0.329\end{array}$

The soldiers of these two species are very similar, but those of $R$. breinli have darker heads and darker and stouter setae on head, thorax and abdomen.

From imagos collected by me in Northern Territory and identified by $\mathrm{Mr}$. Froggatt as $R$. intermedius Brauer, and from others from Mt. Tambourine, Queensland, collected and similarly identified by Dr. Mjöberg, $R$. breinli is distinguished, inter alia, by its smaller size and smaller eyes; these two, however, are not conspecific, Dr. Mjöberg's specimens being eonsiderably larger and more robust, and having larger eyes than those from the Northern Territory. Unfortunately, I have not had for comparison the soldier castes from the same nest series as the imagos in the ease of Brauer's species (as identified by Froggatt), but I have compared both forms of soldiers of $R$. breinli with specimens from Mackay, Q., from Mr. Froggatt's collection, and find them to differ markedly in the colour and shape of the head.

*Measurements and other particulars are from co-types from Kalgoorlie, W. Australia. 
The nearest ally of $R$. breinli appears to be a rather larger species from Magnetic Island, Q. Of this species I have at present only a young king and queen, taken under a $\log$ (10th Feb,), and several series of soldiers and workers from $\operatorname{logs}$ and trees in the vicinity, which may be conspecific, but the material is insufficient to describe as a new species in such a difficult genus. For the same reason I have withheld deseriptions of a very distinct species from Malanda, Atherton Distriet, N.Q., and other apparently distinet species. I can find no differences between my new species and an imago from Kimberley, N.W.A., collected and identified by Dr. Mjöberg as $R$. reticulatus Froggatt.

Biology: This is one of the common species of termite found in the Townsville district, where it causes very considerable damage to wooden houses and fences and probably ranks next to Mastotermes darwiniensis in economic importance. It is met with frequently in bush localities, under and within fallen logs, in tree trunks and under the generally fragile clayey covering with which it encases dead trees and fence posts. The trunks of Pandanus sp. are very often attacked and completely destroyed; house-blocks are occasionally attacked and large numbers of soldiers and workers have been found in the earthen termitaria of Hamitermes perplexus Hill.

On several occasions the wooden portion of the Australian Institute of Tropical Medicine has been attacked, and on one oceasion some damaged timber had to be replaced as a result of infestation by these insects. This building was constructed on a plan quite unsuited to the requirements of a termite-infested locality, the main uprights (Australian hardwood) passing through the concrete floor into the soil below, thus affording an easy means of access to the softwood plates and lining boards.

Hardwood feneing is often badly damaged by these termites, but as the infested portions are nearly always encased in a protecting layer of earthy matter their presence is easily detected and remedial measures can be taken.

Nothing is known concerning the origin of new colonies of this or any other Australian Rhinotermes, but it is surmised that they are founded late in summer by a pair of imagos from the parent colony, as is known to be the ease in two undeseribed species, young kings and queens of which have been found in pairs under logs, subsequent to fertilization of the females, but prior to oviposition. There is a good deal of evidence to support the belief that all the imagos (winged adults) do not leave the parent colony together in one "colonising" flight, as do many species, but that "swarming" takes place over a period of some months.

Mature first form (true) kings and queens and neoteinic kings and queens are not known in Australian species of this genus, nor is there any record of the discovery of a nest. In a previous paper (Hill, 1915) I have recorded having found a mound occupied solely by a species of Rhinotermes, but in the light of further knowledge I now consider this termitarium to have been the work of a species belonging to some other genus and that termitaria are never constructed by Rhinotermes. All the evidence to hand is in support of the contention that the nest is situated at some considerable depth below the surface of the ground, possibly 4 or 5 feet, since none of the scores of colonies in logs, trees, and posts, investigated here and elsewhere, have contained eggs or royal forms, though young larvae and nymphae are frequently present with the soldiers and workers.

Of the two forms of soldiers the smaller appear to outnumber the larger in about the proportion of 4 to 1 , the total of the two being about $25 \%$ of the workers. Both forms contain individuals of male and female sex, the smaller form being the most active and aggressive. 
A few alate male and female imagos were captured at a lamp in a Townsville residence on each of the following nights:-3/3/19, 8/12/19, $7 / 1 / 20$, $15 / 2 / 20,5 / 3 / 20,24 / 1 / 21,26 / 1 / 21,8 / 2 / 21,28 / 2 / 21,2 / 3 / 21,8 / 3 / 21,10 / 3 / 21$, $7 / 4 / 21$. On 24th January and 8th March many alate male and females were taken under the clayey casing enveloping fence posts in Townsville and on 21st February still greater numbers were found under somewhat similar cireumstances at Rollingstone. In each ease the wood had been seriously damaged. The winged forms, like the soldiers and workers, are very active and when disturbed retreat rapidly to eracks and erevices, preferring to hide rather than to take wing.

Named in honour of Dr. Anton Breinl, formerly Director of the Australian Institute of Tropical Medicine.

Loc.-N. Queensland: Rollingstone, Townsville (G. F. Hill); ? N.W. Australia: Kimberley (Dr. E. Mjöberg).

\section{Subfamily TERMITINAE.}

Genus E U T E R M E S Fr. Mull.

Eutermes westraliensis, n. sp. (Figs. 51-56.)

\section{I $m$ a $g$ o.}

Not known.

$$
\text { Soldier. (Figs. 51-53.) }
$$

Colour: Head very dark, almost black; rostrum rather darker than posterior portion; antennae, thorax, femora, and tergites of abdomen mummy brown; under surface, tibiae, tarsi, and palpi dresden brown.
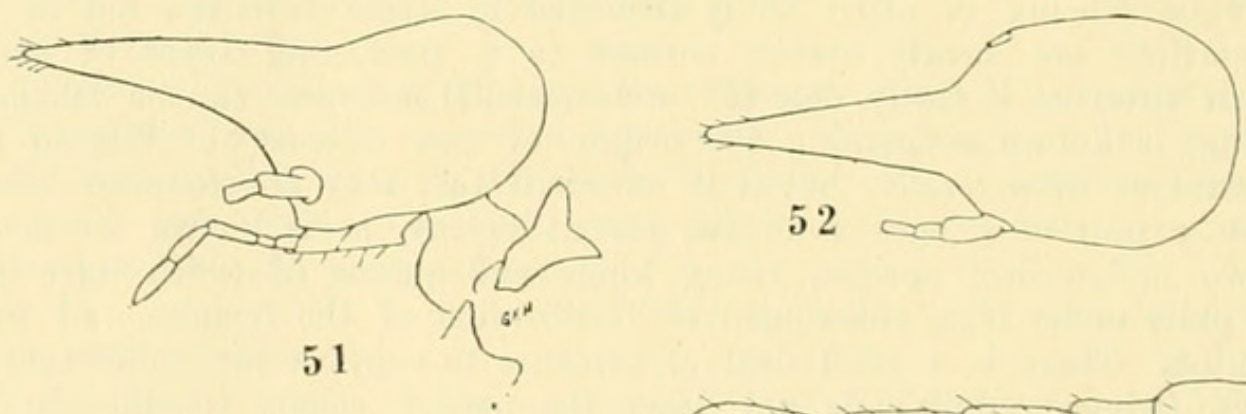

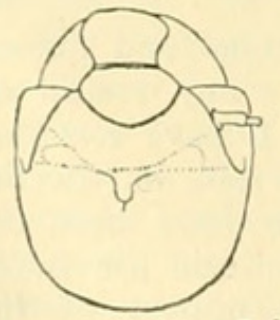

54

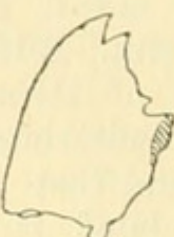

55

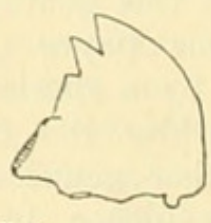

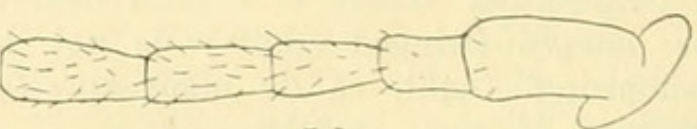

53

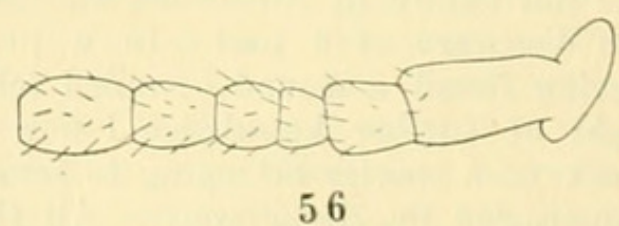

56

Eutermes westraliensis, n.sp.

Figs. 51-53. Soldier. 51. Head in profile; 52. Head from above;

53. Antennae, proximal segments.

Figs. 54-56. Worker. 54. Head; 55. Mandibles; 56. Antennae, proximal segment's.

Head (Figs. 51 and 52) very long and slender, rounded behind, sloping on the sides to the long, stout rostrum; rostrum as long as remainder of head, slightly convex above in the profile; front of head depressed; a few short setae 
on rostrum, remainder of head almost bare. Antennae (Fig. 53) very long (3.10) and slender, 15-jointed (rarely 14-jointed), 1st joint more than twice as long as 2nd, 2nd shortest, 3rd and 4th generally subequal, or 3rd sometimes markedly longer than 4th, 5th a little longer than 4th, slightly turbinate like succeeding joints, 6th longer than 5th, 7th and 8th longer, subequal, 9th, 10th, 11th and 12th longest of all, twice as long as 2nd, 13th and 14th shorter, subequal, equal to 6 th, 15th shorter than 14 th, as long as 4th, 16th shorter than 15th, bluntly rounded at apex.

Thorax with shining, minutely-wrinkled surface, clothed very sparsely with very small setae invisible under hand lens. Pronotum: Saddle-shaped anterior margin with a few minute setae, otherwise bare; anterior margin bent up sharply, bilobed in front, very dark in colour, antero-lateral angles rounded, sides sloping to the nearly round posterior margin; posterior half broadly margined with mummy brown, median suture and small spot in middle pale. Mesonotum reniform, a little narrower than pronotum, half as long as wide. Metanotum much wider but shorter than mesonotum, nearly three times as wide as long.

Legs very long and slender, almost eylindrical, as dark as thorax when viewed from above, sparsely elothed with short fine setae.

Abdomen very little contracted at base and not markedly wide in middle, rounded at apex; apices of tergites with a few short fine setae, remainder elothed with minute setae. Cerci very long and slender.

Measurements :

Total length 4.50 .

Head, long 1.88 ; wide 0.987 .

Pronotum, long 0.330 ; wide 0.564 .

Tibia i. 1.410 ; ii. 1.457 ; iii. 2.021.

Abdomen, wide 1.175 .

$$
\text { Worker. (Figs. 54-56.) }
$$

Colour: Head sepia, with clear median suture extending from the posterior margin to the fontanelle, where it divides in the shape of the letter "U," each arm extending laterally across the head to a clear area lying midway between the posterior margin of the antennal fossae and the fontanelle; clypeus buffy brown; labrum yellow, thorax and abdomen slightly paler than in soldier; legs whitish.

Head (Fig. 54) moderately large, almost hairless, rounded behind and on the sides, widest in front, flat on the summit. Clypeus twice as wide as long, strongly convex behind, truncate in front, with obseure median suture. Anteclypeus hardly visible. Labrum narrow at base, swollen on the sides, truncate in front, not quite covering the apical teeth of mandibles. Mandibles (Fig. 55). Antennae (Fig. 56) long and slender, 17-jointed, 3rd joint shortest of all, 4th and 5th subequal, 6th much longer.

Thorax very similar to that of soldier, a little paler in colour.

Legs long and slender, with sparse clothing of fine setae.

Abdomen short and narrow, with dark tergites, as in soldier. Cerei of moderate length.

Measurements :

Total length 5.50 .

Head from base to posterior margin of clypeus, long 1.269 ; wide 1.504 .

Pronotum, long 0.517 ; wide 0.799 .

Tibia i. 1.316 ; ii. 1.410 ; iii. 2.068.

Abdomen, wide 1.05 . 
Affinities: This species is easily distinguished from all previously described Australian Eutermes by the shape of the head of the soldier. Additional characters which serve to differentiate it from nearly all other species are:-its nearly black head, very long, slender, dark legs and antennae and the distinctly banded appearance of the abdomen. Some, or perhaps all, of these latter characters occur in a few Northern Australian species; but never in conjunction with a remarkably long rostrum and slender head.

Biology: I am indebted to Mr. J. Clark for the following information:The termitaria are numerous on the open, sandy, coastal plains and on the Darling Range. They vary in shape, some being narrow and conical, others wide and flat. The average size is about 10-12 inches high and 16-18 inches wide at the base, but occasionally they are twice this size. In many eases they appear to be built upon roots or stumps. The outer walls are about one and one-half inches thick and protect an interior composed of very large cells or chambers, all of which are filled with short lengths of grass. There appears to be neither "nursery" nor queen cell in the super-structure and as the mature reproductive forms have not yet been discovered in any of the nests examined it is probable that the termitarium serves the purpose of a storehouse only. When the nests are broken the workers appear to be more aggressive than the soldiers, and are often noticed running about holding other species in their jaws.

In the nests of many species of Eutermes there is no regular queen-cell, the ovigerous female ovipositing in any of the large cells towards the outer walls that are not already filled with "chaffed" grass. In others the termitarium serves as a storehouse and nursery, the queen and eggs being located below the surface of the ground, as would appear to be the case in the species described above. It is by no means a rare occurrence to find two or more species of termites living in one termitarium, but Mr. Clark's record of five species is very unusual. Hamitermes obeuntis Silv. and Mirotermes kraepelini Silv. are often associated in the nests of other species, but in one nest of Eutermes westraliensis there were found, in addition to the two above species, Leucotermes, n. sp. and Eutermes? apiocephalus Silv.

Loc.-S.W. Australia: Gosnells, Kalamunda, Wongong (J. Clark).

\section{References in addition to those quoted in the text.}

Hill, G. F., 1921.-Coptotermes raffrayi Wasman. Proc. Limn. Soc. N.S. Wales, xlvi., Pt. 2, pp. 263-267.

- On some Australian Termites of the genera Drepanotermes, Hamitermes and Leucotermes. Bull. Entomological Research (In the Press).

\section{EXPLANATION OË PLATE XXXVI.}

Fig. 4. Stolotermes victoriensis, n.sp. Wings.

Fig. 23. Calotermes (Glyptotermes)? obscurus Walker. Wings.

Fig. 25. , , , , Portion of median vein and membrane.

Fig. 26. Calotermes (Cryptotermes) primus, n.sp. Wings. 


\section{$2 \mathrm{BHL}$ Biodiversity Heritage Library}

Hill, G F. 1921. "New and rare Australian termites, with notes on their biology." Proceedings of the Linnean Society of New South Wales 46, 433-456. https://doi.org/10.5962/bhl.part.14032.

View This Item Online: https://www.biodiversitylibrary.org/item/23930

DOI: https://doi.org/10.5962/bhl.part.14032

Permalink: https://www.biodiversitylibrary.org/partpdf/14032

\section{Holding Institution}

MBLWHOI Library

Sponsored by

MBLWHOI Library

\section{Copyright \& Reuse}

Copyright Status: NOT_IN_COPYRIGHT

This document was created from content at the Biodiversity Heritage Library, the world's largest open access digital library for biodiversity literature and archives. Visit BHL at https://www.biodiversitylibrary.org. 